International Research Journal of Management, IT \& Social Sciences
Available online at https://sloap.org/journals/index.php/irjmis/
Vol. 8 No. 2, March 2021, pages: 175-183
$\begin{aligned} & \text { ISSN: 2395-7492 } \\ & \text { https://doi.org/10.21744/irjmis.v8n2.1400 }\end{aligned}$

\title{
Factors Affecting the Performance of the Head of the Liang State Government of Salahutu District Central Maluku District
}

\begin{tabular}{|c|c|}
\hline & $\begin{array}{r}\text { Judy de Fretes } \\
\text { Nurainy Latuconsina } \\
\text { Atikah Khairunissa }\end{array}$ \\
\hline Article history: & Abstract \\
\hline $\begin{array}{l}\text { Submitted: } 27 \text { January } 2021 \\
\text { Revised: } 18 \text { February } 2021 \\
\text { Accepted: } 09 \text { March } 2021\end{array}$ & $\begin{array}{l}\text { The problem that occurs in the implementation of the state government is that } \\
\text { the implementation of development policies has not been able to run optimally } \\
\text { because of the state's change. Conflict in the head of the king's election, which } \\
\text { has resulted in no country government heads being elected directly and } \\
\text { becoming the definitive leader. Qualitative research methods are used to make } \\
\text { direct observations in the field. The research results show that there is a lack }\end{array}$ \\
\hline \multirow[t]{2}{*}{$\begin{array}{l}\text { Keywords: } \\
\text { electoral conflict; } \\
\text { government performance; } \\
\text { public administration; }\end{array}$} & $\begin{array}{l}\text { of evaluation from the local government so that the problem of the emptiness } \\
\text { of the king is not only in Liang Country but also in other customary countries } \\
\text { in Central Maluku district. The implementation runs optimally because the } \\
\text { head of state officials carrying out their duties properly and planning the } \\
\text { country's development involves the community to participate actively. }\end{array}$ \\
\hline & $\begin{array}{r}\text { International research journal of management, IT and social sciences }(2021 . \\
\text { This is an open access article under the CC BY-NC-ND license } \\
\text { (https://creativecommons.org/licenses/by-nc-nd/4.0/). }\end{array}$ \\
\hline \multicolumn{2}{|c|}{$\begin{array}{l}\text { Corresponding author: } \\
\text { Judy de Fretes } \\
\text { Universitas Pattimura, Indonesia, } \\
\text { Email address: defretesjudy@gmail.com }\end{array}$} \\
\hline
\end{tabular}

\footnotetext{
Universitas Pattimura, Indonesia.

${ }^{\mathrm{b}}$ Universitas Pattimura, Indonesia. Email: nurainy.latuconsina123@ gmail.com

Universitas Pattimura, Indonesia. Email: abinfa95@ gmail.com
} 


\section{Introduction}

In general, in Indonesia, a village (or what is called by another name according to the local language) can be the smallest area managed formally and independently by community groups living in it with mutually agreed-upon rules to create order. Happiness and mutual welfare are considered the collective right and responsibility of this community group. Centralization politics was felt during the $70 \mathrm{~s}$, when the strategic political policies that were rolled out (regulations in the form of regional government laws) uniformed governance in rural areas, including the designation and system of "villages" known in Java. It is different from many regions in Indonesia that use a conventional system that still recognizes the Nagari, village, hamlet, country system, and so on, complete with governance procedures and authority and power. Uniformity, as referred to above, is intended more as a strategy to avoid the nation's disintegration; this is a crime because slowly, this condition has eliminated the cultural richness of the Indonesian people who have lived and developed amid our society (Daniels \& Al-Jumaily, 1975; Sawacha et al., 1999; Iyer \& Jha, 2005).

The enactment of Law Number 5 of 1979 concerning Village Government states in Article 1 letter a that: "A village is an area occupied by several residents as a community unit including a legal community unit which has the lowest government organization directly under sub-district the and has the right to manage its household within the ties of the Unitary State of the Republic of Indonesia." Has eliminated the concept of a country for a customary law community unit in Maluku because, in Law Number 5 of 1979, there is no other mention of the village.

Issued Law Number 32 of 2004 concerning Regional Government and Government Regulation Number 72 of 2005 concerning Villages, stipulating a Village or what is referred to by another name, is a standard community unit that has territorial borders, is authorized to regulate and manage the interests of the local community based on origin. Local proposals and customs are recognized and respected in the Government system of the Unitary State of the Republic of Indonesia and are located in a Regency/City. This refers to Article 18B of the 1945 Constitution (after being amended), which rests on regulating the village, namely diversity, participation, genuine autonomy, democracy, and community empowerment.

Even though they experienced ups and downs as a result of government policies implemented in the past, indigenous peoples in Ambon Island and Central Maluku Regency still encounter or still reflect traditional values, including 1) Indigenous countries still have customary institutions such as Saniri, Soa, Kwang, Marino, and so on; 2) Having a petulant area; 3) Has traditional symbols, namely Baileo (Traditional House), Batu Pamale; 4) Conducting traditional ceremonies and events; 5) Still using indigenous or land languages in traditional ceremonies and formal meetings.

Customary communities or known as customary law community units and their governmental apparatus, have been around for a long time, have lived and developed, and are maintained in the community's social order. The alliance of customary law communities in Maluku has long been very influential in various aspects, including governance, economy, management and control of natural resources, etc. Especially in Maluku, the village's mention is known by several terms, including in Central Maluku Regency, it is known as country, while in the Kei Islands, it is known as Ohio. State Administration is a sub-system of national government within the Unitary State of the Republic of Indonesia, which has the authority to regulate and manage its people's interests.

In customary lands, those who can become Kings come from Soa Parentah (Order) and cannot be taken from other SOA. This then caused unrest among indigenous peoples in Central Maluku Regency because the King's candidate's selection and determination were only for individual citizens. State children who are competent and can become King must be eliminated and do not have the competence opportunity to become number one in their country. Each SOA consists of several clans, but not all of these clans have the right to become a king and those clans who later claimed to each other that they were descendants of the King and had the right to become Kings (Carleton et al., 2001; Ghazvini \& Khajehpour, 2011; Atuahene-Gima, 1996).

Moreover, the weakness in Maluku, especially in Central Maluku, is that the recognition given to a specific person or clan to become King is not accommodated or stipulated in a regulation that has permanent legal force. This recognition is only known through the history that is told (History of Tutor, conveyed or told by word of mouth by a person to their descendants from generation to generation, the existence of community recognition, and evidence of traditional symbols owned). This history is conveyed by the Elders (elders, traditional elders, people who are respected, people who know their country's legal history).

The reality is that many customary countries in Central Maluku Regency do not yet have a definitive Head of State Government. At the same time, the Regional Government of Central Maluku Regency has issued Regional Regulation Number 03 of 2006 concerning Procedures for Determining and Election of Heads of State Government. In this Regional Regulation, the procedures and mechanisms for nominating, electing, and inaugurating the Head of the State 
Government shall regulate without neglecting the principles of customary law and the prevailing laws and regulations. Meanwhile, the wheels of government must run so that to fill the void of the leadership of the Head of the State Government (King), the local government will appoint and appoint the people chosen to become the Acting Head of the State Government (Acting King).

The Acting Head of the State Government carries out the duties, powers, and obligations and obtains the same rights as the State Government Head. The Acting Head of the State Government who fills the Head of the State Government's vacancy in carrying out his duties must prioritize the election of the Head of the State Government Definitively, according to the time limit, which is only six months. Moreover, at the time of the inauguration, the Regent also advised the officials to select the Definitive King. Besides carrying out other duties as Acting Head of government, which is temporary, as happened realistically, it shows that most of the officers cannot process the Definitive King's nomination and election. There are even countries that officials have led for more than 10 to 30 years. Even one person became an official in two countries, one of which was Liang and Tulehu.

As one of the indigenous countries, Liang Country does not yet have a definitive Head of Government, so the Acting Head of Government leads Liang Country. This has been going on for about 20 years. Even from 2015 to 2018 , country Liang was led by Acting Hasanres Lestaluhu whom the Regent also appointed to serve as Acting Head of the Tulehu State Government. Although it did not last long, it lasted for about seven months. This then became a question for many people, including the people of Liang Country, "The question is, is the Central Government in crisis human resources so that it has to keep Lestaluhu as the office even though it has failed and is given the authority to lead two customary countries in Salahutu? Do not let the position be oriented only to village fund projects."

\section{Materials and Methods}

Qualitative methodology is a research procedure that produces descriptive data in written and spoken words from people and observable behavior. The data collected results from the field were obtained through primary data collection such as observation, interviews, literature study, and secondary data collection such as supporting data obtained from existing archives/documents or written literature closely related to the research title (Bogdan et al., 1975; Flick, 2013; Willig \& Rogers, 2017). Meanwhile, the method of observation, according to Berg (2001) is a systematic observation and recording of a symptom that appears on the object of research.

\section{Results and Discussions}

\section{Village government}

The Village Head is a leader in the village administration where is directly elected by villagers who are citizens of the Republic of Indonesia whose further requirements and election procedures are regulated by regional regulations dominating regional regulations guided by government regulations. Article 26 of Law Number 6 of 2014 concerning Villages states that the Village Head has to carry out government, development, and community affairs. The governmental affairs in question are community life regulations following village authority, such as making village regulations, establishing community institutions, establishing village-owned enterprises, and cooperation between villages. The development affairs in question are community empowerment in providing facilities and infrastructure for village public facilities.

In carrying out the duties and obligations of the Village Head, he is obliged to submit a report on the administration of the village administration at the end of each fiscal year. To the Regent or Mayor and submit a report on the implementation of village governance at the end of the office term. To the Regent or Mayor, provide a written statement of government administration to the Regional representative body at the end of each fiscal year and provide or disseminate written governance information to the village community. Distribution of village funds for state development through deliberation stages, which is carried out jointly between the state government, the senior agency, and the community (Tuanaya et al., 2020; Kaliky et al., 2020).

Based on the description above, it can be seen that the Village Head has a huge role in advancing development to improve the lives of the people of his Village. As the main and highest leader, he is also given power as the main person in charge of all activities. Simultaneously, the village apparatus consists of the Village Secretary, regional administrators, and technical implementation of the village apparatus, who are tasked with assisting the Village Head

Fretes, J. de, Latuconsina, N., \& Khairunissa, A. (2021). Factors affecting the performance of the head of the liang state government of salahutu district central maluku district. International Research Journal of Management, IT and Social Sciences, 8(2), 175-183. https://doi.org/10.21744/irjmis.v8n2.1400 
carrying out his duties and authorities. The Village Head appoints village officials after being consulted with the camat on behalf of the Regent / Mayor. In carrying out their duties, the village apparatus is accountable to the Village Head.

\section{Government of the Land}

The Village is the smallest unit of government in the country. Article 18B paragraph (2) of the 1945 Constitution of the Republic of Indonesia states that the Unitary State of the Republic of Indonesia is divided into provincial areas, and provincial areas are divided into regencies and cities, each of which has a regional government. The basis for village regulation is the 1945 Constitution of the Republic of Indonesia, which stipulates that the state recognizes and respects indigenous peoples and their traditional rights as long as they are still alive and by community development and the Unitary State's principles, the Republic of Indonesia. Furthermore, according to Wijaya (2015), the definition of traditional institutions is: "Community organizations are formed as a forum to foster, preserve and develop customs as norms, rules with social beliefs that grow and develop in society, all activities are to maintain, empower, protect and develop customs and traditions that need to be preserved in an ongoing manner".

As another name for Village, the country in Maluku Provincial Regulation Number 14 of 2005 is defined as a genealogical-territorial customary community unit that has territorial boundaries, has the right to regulate and manage the interests of the local community based on the origin and local customs residing in Maluku Province which is recognized and respected in the ties of the Government of the Unitary State of the Republic of Indonesia. The government and the community are consistent in implementing customary provisions in the election of a king.

However, nowadays, the community is experiencing a change of mind in terms of customary provisions regarding a king's election (Touwe et al., 2020; Chanana \& Gupta, 2016; Kawiana et al., 2018). In Article 6 in paragraph (2) of Law Number 6 of 2014, it is permissible to mention Village / Traditional Village to be adjusted to the designation that applies in the local area. As another name for Village, the country has similarities when compared with the term Nagari in the Sumatra region, or Gampong, known in Acehnese society. According to Geertz (1976); Geertz (1973) that the word Nagari or Negara comes from Sanskrit, which means "city," which in Indonesian is used interchangeably with the term "capital," "country," "kingdom," or "city." On the other hand, the term village is also absorbed from the Sanskrit language, namely Dhesi, which means "land of birth. Some interpret it as suburbs or areas that are ruled or dependent on a higher power. An institution is a form of organization that is composed relatively fixed of patterns. Behavior, roles, and directed and increasing individual relations have formal authority and legal sanctions to achieve basic social needs (Marbun, 2014).

The government administration in the country cannot be separated from state apparatuses such as Saniri, or the Village, referred to as the Village Consultative Body, the King or Village Head, and various other traditional instruments that exist in the country systemically. To realize effective performance by the state apparatus, according to Siagian (1982) the development of state apparatus or village apparatus can be said to be successful if in the organization physical and spiritual satisfaction is obtained at the State Apparatus or apparatus at all levels, all of which are organizations that can progress according to plan. The structure is a logical collection of layers in the legal system concerned (Rais \& Simulie, 2000).

Government performance has begun to become the primary concern of the government, in this case, the regional government as a technical implementation unit in the region when regional autonomy is realized, as mandated by Law No. 32 of 2004 concerning Regional Government, has given a strong signal to accommodate local wisdom, namely that there is recognition of local wisdom. Village regulations in the hierarchy of national legislation. The contestation arena for the king's election has several modalities, namely cultural capital, political capital, social capital (Wance, 2019).

This accommodation automatically empowers the state government and traditional institutions that have existed for a long time with the people concerned so that in the process of public policy by the government. It must embrace society elements; of course, it is not a difficult thing for the government because customary functionaries can provide information about the order and structure of society that he dreams of as a database for the government in formulating public policies. The community can judge that the Saniri Body was formed as long as it was not by the customary mechanism but through the appointment of the people closest to the king (Head of the State Government) (Wance et al., 2020).

This means that within the scope of government, the management and utilization of natural and human resources as a source of village income and village development management patterns, where the priority scale refers to the physical village and the mental attitude of the community (Surianingrat, 1980; Aslan, 2019; Aslan et al., 2020). In connection with this problem, harmony and work harmony between officials, both structure and function in the village, 
are essential for the village's smooth running. The concept of harmony and harmony in the relationship between state governments and customary institutions must be considered because many villages are also caused by differences in interpretation between the state government and traditional institutions.

These different interpretations sometimes impact differences in policies and attitudes, giving rise to the dualism of decisions that impact divisions in society. A new paradigm of public administration emerged by formulating a series of idealisms and practices related to the use of absolute values and norms to implement public service accountability (Herizal et al., 2020). From the results of interviews and observations while at the research location, it was found that the temporary officials in the country Liang had made several changes and the appointment of this interim acting was directly by the district head of Central Maluku. It is just that the main task of the interim acting, in this case, is to prepare a definitive king until now has not been realized. The longing for a definitive king in Liang country considering that Liang country has almost 21 years without a definitive king. Even though the regulations and rules in the Central Maluku Regional Regulation No. 3 of 2006 concerning the procedures for nominating, electing, and electing the state government's head are apparent to make as a legal basis and reference, even the definitive Saniri has been confirmed since 2017. The determinant factor affects the Acting Head of State Government in the implementation of the definitive King election in Salahutu District, Central Maluku Regency.

The interim acting in Liang country has made several changes and the appointment of this interim acting directly by the Central Maluku regent. The interim acting so far regarding public services is quite useful in Liang country; it is just that the quick acting's main task is to prepare a definitive king. Until now, it has not been realized. The dream of a definitive king in Liang, considering that Liang has been nearly 21 years without a definitive king. Even though the regulations and rules in the Maluku Tengah regional regulation no 3 of 2006 concerning the procedures for nominating, electing, and electing the head of the state government are obvious to make as a legal basis and reference, even senior Negara that has been inaugurated since 2017 until now has not been able to exercise its authority. Properly, among other things, proposing the appointment and dismissal of the Head of the State Government and forming a committee for the election of the Head of the State Government.

From the research results, it is found that several determinants that affect the performance of the Acting Head of State Government in the implementation of the definitive King election in the country include:

Officials are also given the authority to carry out the task of running the government Temporary Village Officials appointed by the Head of the District or the local Regent following the Regulation of the Minister of Home Affairs of the Republic of Indonesia Number 82 of 2015 concerning the Appointment and Dismissal of Village Heads. Regulation, No 82 of 2015 above in article 4A, explains "Candidates for elected Village Heads who died world, is absent or resigns for reasons that can be justified before the inauguration, the elected candidate is declared a failure and the regent/mayor appoints civil servants and district/city Regional Government as Village Head Officials.

On this basis, the power of the Village Government is still held by village officials. Moreover, according to the applicable regulations, an official is given six months to prepare a definitive government head with saniri country. That is the main task or principal of an officer. However, an acting king also carries out the same duties, powers, and obligations as a definitive king, namely administering the country's government, carrying out country development, and fostering and empowering the country's people. When the six-month deadline has passed, the district government will issue a new appointment decree for the office for the next six months of service. Moreover, this will continue for the next one to 2 years. During Lestaluhu's leadership, efforts were made to speed up selecting the king, even going to country Soya, Ambon City, to trace the history of leadership in Liang country. Various attempts were made, but all of them would return to the authority of Saniri. Acting with staff only facilitates it.

Because over the past three years, there has not yet been a definitive king, coupled with the appointment and training of Lestaluhu as officials in Tulehu, which led to the youth and students demanding that the Regent immediately replace the Acting Lestaluhu. They also demanded that the next Acting Officer be a child from Liang's country to know more about the conditions and problems in the country.

Based on an interview with development manager Jorgi Wael, he said: State official Liang M. Ramlan Achmad, is appointed to replace Lestaluhu. He is also not a son of the Liang country, but his wife is a liang. When he was inaugurated, he wanted to stay in office for a long time because he wanted the parent's house to be resolved immediately and immediately process the definitive king. However, we can only facilitate, but the authority lies within the country. Furthermore, now his tenure is over, but it is not confident whether it will continue or be replaced by someone else.

Fretes, J. de, Latuconsina, N., \& Khairunissa, A. (2021). Factors affecting the performance of the head of the liang state government of salahutu district central maluku district. International Research Journal of Management, IT and Social Sciences, 8(2), 175-183. https://doi.org/10.21744/irjmis.v8n2.1400 


\section{Saniri internal problems}

Starting from Saniri country Liang's formation in 2017 based on the Decree of the Regent of Central Maluku No. 141 - 32 of 2007. Several powers relating to the process of determining the Head of Government are owned by Saniri country as regulated in Article 7 of Regional Regulation No. 4 of 2006 concerning Guidelines for Saniri country Structuring, among others are: Proposing the appointment and dismissal of the Head of the State Government and forming a Committee for the Election of the Head of the State Government. One form of implementation of the authority possessed by Saniri country, which is based on local customs and laws, is to determine the Matarumah Command through deliberation with matarumah/descendants.

This is also as stipulated in Article 3 of Regional Regulation No. 1 of 2006 of Central Maluku Regency concerning the Country, namely "The position of Head of State Government is a right of certain descendants which is determined based on the results of the descendants who are entitled to joint Saniri country." Even though Saniri country was formed in 2017, they have not been able to carry out their authority properly, namely to present the head of government or the definitive King of Liang. Based on interviews with general terms which say:

The people of Liang Country longed to have a king, but they have not been able to. The eye of the parent house in country Liang is the Somoal clan. However, not everyone who has the Somoal clan can become King King. Because many Somoal clans claim that they are the eyes of a householder who has the right to become King King, Saniri has not yet been able to proceed. Also, the Soplestuny clan states that they are also descendants of the eye of the house, where they also have evidence of the past. Soplestuny started as Somoal, which over time became a clan. Soplestuny is a title given to one of the kings during his reign. Even though country Liang has not had a definitive King for about 20 years, the definitive Saniri was only formed in 2017. Moreover, after being formed, membership from saniri must be given socialization about its primary duties, functions, and authorities, and even have to follow the technical guidance, which the district government should do. This is to understand and know clearly what their authorities, duties, and functions are.

Since the membership of Saniri itself is a representative of the soa-soa in the land of burrows, they should be firm and carry out their duties according to the Regional Government of Central Maluku's rules and regulations Regency. However, what happens is that there are individual interests in saniri so that saniri itself is split into two camps, and this is unfortunate. It can be said that the performance of saniri also made the country of Liang not yet have a definitive king.

Lack of evaluation from local government. In the framework of the smooth running of governance, development, democracy, and society of the State, a State Government's existence is essential. For this reason, the Central Maluku Regency Government has issued Regional Regulation Number 03 of 2006 concerning Procedures for Election, Appointment, and Dismissal of State Apparatus, which is intended to implement democratic principles in the general government system and customary government. Most of the indigenous peoples in Central Maluku Regency still respect the figure of a leader or King in the Customary Law Community, which is derived from a straight line from the parentah house which cannot be transferred to other parties, except in special cases which are determined based on the results of eye deliberations.

Parent house which has the right to be with Saniri country. In fact, in some customary countries, including country Liang, namely clans that have the right to become King, they have quite a lot of descendants, and each of them claims that their clan is part of the eye of the house and they have the same right to become King. The regional regulations issued by the Central Maluku Regency Government are clear. The community believes that the Regional Government should evaluate problems or conflicts that occur in Indigenous countries so that solutions can be found to solve these problems. One of them is to revise the Central Maluku Regency Government Regulation no. 3 of 2006. Because one of the articles states that the King in customary countries must be based on a straight lineage, this is the reason why Liang has not been able to get a definitive king until now. Because the parentah house's determination must be recognized and received recognition from the people in Liang country, it must also be accommodated in Liang Country regulations. Whoever is elected will be recognized as King, and his descendants will become kings from generation to generation. This will undoubtedly negate the opportunity for other clans who also have the right and are competent to become kings. 


\section{Conclusion}

Based on the research results, the following conclusions can be drawn: The Acting Head of Government understands the duties that are responding well. This can be seen from the proper implementation of duties and responsibilities because the officials are civil servants appointed and appointed by the Regent. It is just that it is related to the main task of presenting a definitive head of government which cannot be carried out properly due to conflicts that occur in the parents' house. The determinant factors that affect the Acting Head of State Government in the implementation of definitive King elections in country Liang, Salahutu District, Central Maluku Regency. Lack of evaluation from the local government so that the king's emptiness is not only in Liang Country but also in other traditions located in Central Maluku district. An official is also given the same authority as a definitive king to carry out the government's task. Apart from that, saniri internal problems because the house eye's determination already exists but has not been followed up by the saniri country. This is because it is not that Saniri country is inconsistent with the prevailing regulations, is not firm, and does not dare to take action, but Saniri country Liang is cautious in determining the parent house's eyes so as not to cause widespread conflict in the future.

\section{Conflict of interest statement}

The authors declared that they have no competing interests.

\section{Statement of authorship}

The authors have a responsibility for the conception and design of the study. The authors have approved the final article.

\section{Acknowledgments}

We, the authors, express our gratitude for all the support from our colleagues to complete this paper according to plan. Likewise, with funding so that we are greatly helped both at the initial stage to the completion stage of work with the theme "Factors Affecting the Performance of the Head of the Liang State Government of Salahutu District Central Maluku District".

Fretes, J. de, Latuconsina, N., \& Khairunissa, A. (2021). Factors affecting the performance of the head of the liang state government of salahutu district central maluku district. International Research Journal of Management, IT and Social Sciences, 8(2), 175-183. https://doi.org/10.21744/irjmis.v8n2.1400 


\section{References}

Aslan. (2019, January 17). Pergeseran Nilai Di Masyarakat Perbatasan (Studi tentang Pendidikan dan Perubahan Sosial di Desa Temajuk Kalimantan Barat) [Disertasi dipublikasikan]. Pasca Sarjana. https://idr.uinantasari.ac.id/10997/

Aslan, Suhari, Antoni, Mauludin, M. A., \& Mr, G. N. K. (2020). Dinamika Keagamaan Masyarakat Perbatasan Paloh Kabupaten Sambas, Kalimantan Barat. Jurnal Antropologi: Isu-Isu Sosial Budaya, 22(1), 90-101. https://doi.org/10.25077/jantro.v22.n1.p90-101.2020

Atuahene-Gima, K. (1996). Differential potency of factors affecting innovation performance in manufacturing and services firms in Australia. Journal of Product Innovation Management, 13(1), 35-52. https://doi.org/10.1016/0737-6782(95)00090-9

Berg, B. L. (2001). Qualitative Research Methods For The Social Sciences. Allyn and bacon.

Bogdan, R., Taylor, S. J., \& Taylor, S. S. (1975). Introduction to Qualitative Research Methods: A Phenomenological Approach to the Social Sciences. Wiley.

Chanana, M., \& Gupta, K. (2016). Quality of work life and its impact on job performance: a study of SBI \& HDFC banking professionals. International Research Journal of Management, IT and Social Sciences, 3(5), 16-24.

Carleton, J. N., Grizzard, T. J., Godrej, A. N., \& Post, H. E. (2001). Factors affecting the performance of stormwater treatment wetlands. Water Research, 35(6), 1552-1562. https://doi.org/10.1016/S0043-1354(00)00416-4

Daniels, T. C., \& Al-Jumaily, F. K. (1975). Investigations of the factors affecting the performance of a rotating heat pipe. International Journal of Heat and Mass Transfer, 18(7-8), 961-973. https://doi.org/10.1016/00179310(75)90190-8

Flick, U. (2013). The SAGE handbook of qualitative data analysis. Sage.

Geertz, C. (1973). The Interpretation Of Cultures. Basic Books, Inc., Publisher.

Geertz, C. (1976). The Religion Of Java. The University Of Chicago Press.

Ghazvini, S. D., \& Khajehpour, M. (2011). Gender differences in factors affecting academic performance of high school students. Procedia-Social and Behavioral Sciences, 15, 1040-1045. https://doi.org/10.1016/j.sbspro.2011.03.236

Herizal, H., Mukhrijal, M., \& Wance, M. (2020). Pendekatan Akuntabilitas Pelayanan Publik Dalam Mengikuti Perubahan Paradigma Baru Administrasi Publik. Journal of Governance and Social Policy, 1(1), 24-34. https://doi.org/10.24815/gaspol.v1i1.17327

Iyer, K. C., \& Jha, K. N. (2005). Factors affecting cost performance: evidence from Indian construction projects. International journal of project management, 23(4), 283-295. https://doi.org/10.1016/j.ijproman.2004.10.003

Kawiana, I. G. P., Dewi, L. K. C., Martini, L. K. B., \& Suardana, I. B. R. (2018). The influence of organizational culture, employee satisfaction, personality, and organizational commitment towards employee performance. International research journal of management, IT and social sciences, 5(3), 35-45.

Kaliky, P. I., Wance, M., \& Matdoan, M. Y. (2020). The Reality of Government Communication in Hitu Lama Negeri Development Planning, Central Maluku Regency. International Research Journal of Management, IT and Social Sciences, 7(6), 153-160. https://doi.org/10.21744/irjmis.v7n6.1031

Marbun, R. (2014). Grand Design Politik Hukum Pidana dan Sistem Hukum Pidana Indonesia Berdasarkan Pancasila dan Undang-Undang Dasar Negara Republik Indonesia 1945. Padjadjaran Journal of Law, 1(3).

Rais, K., \& Simulie, Dt. P. (2000). Hukum Adat Serta Akibat-Akibat Hukumnya. Rajawali Pers.

Siagian, S. P. (1982). Organisasi, kepemimpinan dan perilaku administrasi. Gunung Agung.

Sawacha, E., Naoum, S., \& Fong, D. (1999). Factors affecting safety performance on construction sites. International journal of project management, 17(5), 309-315. https://doi.org/10.1016/S0263-7863(98)00042-8

Surianingrat, B. (1980). Desa dan kelurahan menurut UU no. 5, 1979. Metro Pos.

Touwe, M. A., Tuanaya, W., \& Wance, M. (2020). Sistem Pemilihan Raja Negeri Munarten Kecamatan Taniwel Kabupaten Seram Bagian Barat. Jurnal Studi Ilmu Pemerintahan, 1(2), 1-15.

Tuanaya, W., Muhtar, M., Khairunisa, A., \& Wance, M. (2020). Political Communication in the Determination of Regional Expenditure Budget (APBD) of Ambon City in 2019. Jurnal Ilmiah Tata Sejuta STIA Mataram, 6(1), 76-95.

Wance, M. (2019). Dinamika perencanaan anggaran pada anggaran pendapatan belanja daerah (APBD) buru selatan. The Indonesian Journal of Public Administration (IJPA), 5(1). 
Wance, M., Muhtar, M., \& Kaliky, P. I. (2020). PKM Penyelenggaraan Pemerintahan Dalam Perencanaan Pembangunan Negeri Hila Kabupaten Maluku Tengah. CARADDE: Jurnal Pengabdian Kepada Masyarakat, 2(2), 229-338.

Wijaya, M. H. (2015). Karakteristik Konsep Negara Hukum Pancasila. Jurnal Advokasi, 5(2).

Willig, C., \& Rogers, W. S. (2017). The SAGE handbook of qualitative research in psychology. Sage.

Fretes, J. de, Latuconsina, N., \& Khairunissa, A. (2021). Factors affecting the performance of the head of the liang state government of salahutu district central maluku district. International Research Journal of Management, IT and Social Sciences, 8(2), 175-183. https://doi.org/10.21744/irjmis.v8n2.1400 